\title{
Survey of Plant Parasitic Nematode Associated with Spinach, Swiss Chard and Table Beet in North Egypt
}

\author{
Ayman B. A. Basyony ${ }^{1}$, Ibrahim K. A. Ibrahim ${ }^{1}$ Sabreen M. A. Zeyadah ${ }^{1}$, and Maha A. I. Kawanna ${ }^{1}$
}

\begin{abstract}
A nematode survey was conducted in Alexandria, ElBehera, El-Gharbia, El-Monufia and Kafr El-Sheikh governorates in northern Egypt during the 2017 - 2019 cropping seasons to study the occurrence, population density and host association of plant parasitic nematodes associated with spinach, Swiss chard and table beet. A total of 854 soil and root samples were collected from the rhizosphere of the surveyed vegetable crops. The surveyed governorates and their respective numbers of soil samples were as follows: Alexandria 230, El-Behera 206, ElGharbia 138, El-Monufia 211 and Kafr El-Sheikh 69 samples. Plant parasitic nematodes in the collected soil and root samples were extracted, identified, and counted under the compound light microscope. The collected soil and root samples contained mixed populations of 15 genera and 18 species of phytoparasitic nematodes that are reported for the first time on spinach, Swiss chard and table beet in Egypt. The root-knot nematode (Meloidogyne spp.) with 37 - 67 frequency of occurrence (FO) were the most frequently encountered group of nematodes, followed by spiral (Helicotylenchus sp.), cyst (Heterodera sp.), lesion (Pratylenchus sp.) and stunt (Tylenchorhynchus sp.) with 15 - 61 FO. The genera Criconema, Criconemella and Tylenchus were quite common. However, the other genera (Ditylenchus, Hoplolaimus, Psilenchus, Rotylenchulus, Rotylenchus, Trichodorus, and Xiphinema) were less common. The nematode species Meloidogyne arenaria, $M$. incognita, M. javanica, Heterodera schachtii and $\boldsymbol{H}$. trifolii were identified on spinach, Swiss chard and table beet roots. The occurrence of the cyst nematodes $H$. schachtii and $\boldsymbol{H}$. trifolii on spinach, Swiss chard and table beet are new records in Egypt. Also, survey results revealed new host plant records for most of the identified nematode genera and species in Egypt.
\end{abstract}

Keywords: Nematodes, Survey, Spinach, Swiss chard, Table beet, Egypt.

\section{INTRODUCTION}

In Egypt, plant parasitic nematodes have been recognized as important plant pests since 1901 when Preyer 1901 first reported a nematode disease of banana in Alexandria, Egypt (Ibrahim and El-Sharkawy, 2001; Preyer, 1901). Previous survey studies showed the occurrence of large numbers of genera and species of phytoparasitic nematodes associated with many plant crops, grasses and weeds at different localities in Egypt
(Ibrahim and El-Sharkawy, 2001; Ibrahim et al., 2000; 2010). Many of these nematodes especially Helicotylenchus spp., Hoplolaimus spp., Meloidogyne spp., Pratylenchus spp., Rotylenchulus reniformis, Tylenchorhynchus spp., Tylenchulus semipenetrans and Xiphinema spp. are considered limiting factors in crop production in Egypt (Adam et al., 2013; Korayem et al., 2014; Ibrahim and Handoo, 2015; Ibrahim et al., 2010). Also, the practice of continuous cropping and use of local plant cultivars favor survival and rapid build-up of nematode populations in the soil. Information concerning the occurrence and distribution of the genera and species of phytoparasitic nematodes in Egypt is very important as several of the serious nematode pathogens, i.e. citrus, cyst, lance, lesion, root-knot, spiral and stunt nematodes, may occur in large numbers and cause economic damage to many plant crops. Recent survey studies showed the occurrence of about 59 genera and 170 species of phytoparasitic nematodes associated with many cultivated plants (Ibrahim and Handoo, 2016; Ibrahim et al., 2017). The objective of the present study was to identify plant parasitic nematodes associated with spinach, Swiss chard and table beet plants in north Egypt and provide more extensive information on the distribution of genera and species of plant parasitic nematodes.

\section{MATERIAL AND METHODS}

The present survey was carried out during 2017 2019 cropping seasons. A total of 854 rhizosphere soil samples were randomly collected from spinach, Swiss chard and table beet plants in five Egyptian governorates. The surveyed governorates and their respective numbers of soil samples were as follows: Alexandria 230 (Abbies, El-Amiria, El-Maamoura, Eslah and Khorshid), El-Behera 206 (Abo El-matamir, Bader, Edko, Etay El-Barod, Kafer El-Dawar, Rosetta and Shobrakit), El-Gharbia 138 (Basyoon, Kafer ElZayat, Qtour and Tanta), El-Monufia 211 (Berkt ElSabh, El-Shohada, Shepin El-Kom and Tala) and Kafr El-Sheikh (Desuq, Fowh, Metopes and Qalen) 69 samples. Rhizosphere soil samples of about $1 \mathrm{Kg}$ each were collected from the surveyed plants at a depth of $15-30 \mathrm{~cm}$ and placed in labeled plastic bags. Root samples were washed free of soil and examined for

DOI: $10.21608 / A S E J A I Q J S A E .2020 .128309$

${ }^{1}$ Department of Plant Pathology, Faculty of Agriculture, Alexandria University,

El-Shatby, Alexandria, Egypt.

Corresponding author: E-mail: mahakawanna@yahoo.com

Received November 01, 2020, Accepted, December06, 2020. 
cyst and root-knot nematode infections. Root-knot nematodes were isolated from galled roots and identified by the examination of perineal patterns of adult females as well as the characters of the second stage juveniles (Taylor and Sasser, 1978). Cysts, females and juveniles were extracted from soil and root samples and identified by morphological characteristics (Golden, 1986; Mulvey and Golden, 1983; Subbotin et al., 2010). Nematodes from a composite sample of $250 \mathrm{~cm}^{3}$ soil were extracted by means of Cobb's wet-sieving and centrifugal sugar flotation techniques (Ayoub, 1980). Nematodes were fixed in $2 \%$ formaldehyde solution then identified to genus and counted under a bionocular stereomicroscope (Mai and Lyon 1975; Müller et al., 1985; Handoo, 2000). Frequency of occurrence ([number of positive samples/number of total samples] $\times 100$ ) and nematode density (nematodes per $250 \mathrm{~cm}^{3}$ soil sample) were determined for the identified nematodes in composite samples and recorded.

\section{RESULTS AND DISCUSSION}

Data presented in Table 1 show the frequency of occurrence (FO) and population density (PD) of plant parasitic nematode genera presented in the soil samples collected from spinach, Swiss chard and table beet fields in Alexandria governorate of Egypt. Ten nematode genera were detected in the soil samples of spinach plants while soil samples of Swiss chard and table beet showed the presence of 11 and 8 nematode genera, respectively. The root-knot nematode
(Meloidogyne spp.) were the most frequent nematodes with $55-64 \%$ FO and PD of $234-433 \mathrm{~J}_{2}$ 's $/ 250 \mathrm{~g}$ soil. The genera Tylenchorhynchus, Pratylenchus and Helicotylenchus showed $28-53 \%$ FO and PD of $134-$ 288 nematodes $/ 250 \mathrm{~g}$ soil. The cyst nematodes (Heterodera spp.) exhibited $13-19.5 \%$ FO and PD of $190-263 \mathrm{~J}_{2}$ 's $/ 250 \mathrm{~g}$ soil. On the other hand, the genera Criconema, Criconemella, Ditylenchus, Hoplolaimus, Tylenchus and Xiphinema showed $4.7-25.8 \%$ FO and 63 - 398 nematodes $/ 250 \mathrm{~g}$ soil.

In El-Behera governorate soil samples, fifteen nematode genera were detected in the soil samples of spinach plants while soil samples of Swiss chard and table beet showed the presence of 13 and 12 nematode genera, respectively. The root-knot nematode (Meloidogyne spp.) were the most frequent nematodes with 51.5 - 65.5\% FO and PD of $443-546 \mathrm{~J}_{2}$ 's $/ 250 \mathrm{~g}$ soil. The genera Tylenchorhynchus, Pratylenchus and Helicotylenchus showed $26.4-60.6 \%$ FO and PD of 195.6 - 312.1 nematodes $/ 250 \mathrm{~g}$ soil. The cyst nematodes (Heterodera spp.) exhibited $16.4-31.6 \%$ FO and PD of $293-391 \mathrm{~J}_{2}$ 's $/ 250 \mathrm{~g}$ soil. On the other hand, the genera Criconema, Criconemella, Ditylenchus, Hoplolaimus, Psilenchus, Rotylenchulus, Rotylenchus, Trichodorus, Tylenchus and Xiphinema showed $4.3-12.9 \%$ FO and $76-395$ nematodes $/ 250 \mathrm{~g}$ soil (Table 2).

Table 1. Frequency of occurrence (FO) and population density (PD) of plant parasitic nematode genera present in soil samples of spinach, Swiss chard and table beet plants in Alexandria governorate

\begin{tabular}{lcccccc}
\hline \multirow{1}{*}{ Genus } & \multicolumn{2}{c}{$\begin{array}{c}\text { Spinach } \\
\mathbf{( 1 2 8}^{\mathbf{a}}\end{array}$} & \multicolumn{2}{c}{$\begin{array}{c}\text { Swiss chard } \\
\mathbf{( 5 3 )}\end{array}$} & \multicolumn{2}{c}{$\begin{array}{c}\text { Table beet } \\
(\mathbf{4 9 )}\end{array}$} \\
\cline { 2 - 7 } & FO\% & PD & FO\% & PD & FO\% & PD \\
\hline Criconema & $25.8^{\mathbf{b}}$ & $185.1^{\mathbf{c}}$ & 16.9 & 191.1 & 26.5 & 210 \\
Criconemella & 12.5 & 146.8 & 16.9 & 137.8 & 6.1 & 110 \\
Ditylenchus & ------ & ------ & 11.3 & 200 & ------ & ----- \\
Helicotylenchus & 33.6 & 288.6 & 28.3 & 193.3 & 28.6 & 166.4 \\
Heterodera & 19.5 & 262.8 & 13.2 & 244.3 & 14.3 & 190 \\
Hoplolaimus & 4.7 & 143.7 & 18.9 & 200 & 6.1 & 320 \\
Meloidogyne & 60.2 & 364 & 64.2 & 234.1 & 55.1 & 433 \\
Pratylenchus & 36.7 & 209.3 & 37.7 & 139 & 40.8 & 197 \\
Tylenchorhynchus & 42.2 & 150.4 & 43.4 & 190 & 53.1 & 134 \\
Tylenchus & 14.8 & 197.4 & 9.4 & 398 & ------- & ------ \\
Xiphinema & 5.5 & 135.7 & 5.7 & 63.3 & ------ & ----- \\
\hline
\end{tabular}

$\mathrm{a}=$ Total number of collected soil samples in tested plant.

$\mathrm{b}=$ Number of positive samples/ $\mathrm{a} \times 100$

$\mathrm{c}=$ Average number of nematodes $/ 250 \mathrm{~g}$ soil. 
Table 2. Frequency of occurrence (FO) and population density (PD) of plant parasitic nematode genera present in soil samples of spanich, Swiss chard and table beet plants in El-Behera governorate

\begin{tabular}{lcccccc}
\hline \multirow{1}{*}{\multicolumn{1}{c}{ Genus }} & \multicolumn{2}{c}{$\begin{array}{c}\text { Spinach } \\
(\mathbf{1 1 6})^{\mathbf{a}}\end{array}$} & \multicolumn{2}{c}{$\begin{array}{c}\text { Swiss chard } \\
\mathbf{( 3 3 )}\end{array}$} & \multicolumn{2}{c}{$\begin{array}{c}\text { Table beet } \\
(\mathbf{5 7 )}\end{array}$} \\
\cline { 2 - 7 } & $\mathbf{F O \%}$ & $\mathbf{P D}$ & $\mathbf{F O \%}$ & $\mathbf{P D}$ & FO\% & PD \\
\hline Criconema & $12.9^{\mathbf{b}}$ & $250^{\mathbf{c}}$ & 9.1 & 223.3 & 12.3 & 232.8 \\
Criconemella & 12.1 & 200 & 12.1 & 295 & 8.8 & 210 \\
Ditylenchus & 4.3 & 124 & 6.1 & 150 & 8.8 & 180 \\
Helicotylenchus & 39.7 & 312.1 & 33.3 & 260.9 & 26.4 & 275 \\
Heterodera & 16.4 & 292.6 & 21.2 & 348.6 & 31.6 & 391.1 \\
Hoplolaimus & 12.1 & 262.1 & 9.1 & 280 & 8.8 & 256 \\
Meloidogyne & 65.5 & 545.5 & 51.5 & 442.9 & 57.9 & 482.4 \\
Pratylenchus & 35.3 & 296 & 59.5 & 216.8 & 60.6 & 280.9 \\
Psilenchus & 4.3 & 177 & 12.1 & 262.5 & ------ & ------ \\
Rotylenchulus & 5.2 & 151.6 & ------- & ----- & ----- & ----- \\
Rotylenchus & 6.1 & 101.4 & 9.1 & 86.7 & 5.3 & 105 \\
Trichodorus & 4.3 & 224 & ------- & ------ & ------- & ----- \\
Tylenchorhynchus & 33.6 & 242.8 & 27.3 & 195.6 & 40.4 & 262.6 \\
Tylenchus & 11.2 & 372.3 & 6.1 & 395 & 7.1 & 210 \\
Xiphinema & 4.3 & 76 & 9.1 & 165 & 5.3 & 165.6 \\
\hline
\end{tabular}

$\mathrm{a}=$ Total number of collected soil samples in tested plant.

$\mathrm{b}=$ Number of positive samples/ $\mathrm{a} \times 100$

$\mathrm{c}=$ Average number of nematodes $/ 250 \mathrm{~g}$ soil.

In El-Gharbia governorate soil samples, ten nematode genera were detected in the soil samples of spinach plants while soil samples of Swiss chard and table beet showed the presence of 9 and 8 nematode genera, respectively. The genera Helicotylenchus was the most frequent nematodes with $25-55 \% \mathrm{FO}$ and PD of $212-307 \mathrm{~J}_{2} \mathrm{~s} / 250 \mathrm{~g}$ soil. The root-knot nematode (Meloidogyne spp.) exhibited $40-48 \%$ FO and PD of
$308-490 \mathrm{~J}_{2}$ 's $/ 250 \mathrm{~g}$ soil. The genera Tylenchorhynchus and Pratylenchus showed $20-36 \%$ FO and PD of 138 - 227 nematodes $/ 250 \mathrm{~g}$ soil. The cyst nematodes (Heterodera spp.) exhibited $19-23 \%$ FO and PD of $189-317 \mathrm{~J}_{2}$ 's $/ 250 \mathrm{~g}$ soil. On the other hand, the genera Criconema, Criconemella, Hoplolaimus, Trichodorus, and Tylenchus showed 5-35\% FO and $100-330$ nematodes /250 g soil (Table 3).

Table 3. Frequency of occurrence (FO) and population density (PD) of plant parasitic nematode genera present in soil samples of spanich, Swiss chard and table beet plants in El-Gharbia governorate

\begin{tabular}{|c|c|c|c|c|c|c|}
\hline \multirow{2}{*}{ Genus } & \multicolumn{2}{|c|}{$\begin{array}{c}\text { Spinach } \\
(67)^{\mathrm{a}}\end{array}$} & \multicolumn{2}{|c|}{$\begin{array}{l}\text { Swiss chard } \\
\text { (31) }\end{array}$} & \multicolumn{2}{|c|}{$\begin{array}{c}\text { Table beet } \\
\text { (40) }\end{array}$} \\
\hline & FO\% & PD & FO\% & PD & FO\% & PD \\
\hline Criconema & $17.9^{b}$ & $196.6^{\mathbf{c}}$ & 19.4 & 169.2 & 35 & 111.4 \\
\hline Criconemella & 4.5 & 123 & 16.1 & 170 & 15 & 166.6 \\
\hline Helicotylenchus & 25.4 & 306.5 & 54.8 & 211.5 & 52.5 & 251.9 \\
\hline Heterodera & 19.4 & 260 & 22.6 & 188.7 & 22.5 & 316.6 \\
\hline Hoplolaimus & 10.4 & 235.7 & ------ & ---- & 12.5 & 148 \\
\hline Meloidogyne & 46.2 & 490.3 & 48.4 & 307.9 & 40 & 407.5 \\
\hline Pratylenchus & 32.8 & 138.6 & 27.6 & 227.1 & 20 & 157.5 \\
\hline Trichodorus & 13.4 & 155.6 & 19.4 & 216.7 & ----- & ----- \\
\hline Tylenchorhynchus & 29.9 & 167.5 & 35.5 & 137.9 & 30 & 167.5 \\
\hline Tylenchus & 11.9 & 330 & 12.9 & 100 & ------ & ----- \\
\hline
\end{tabular}

$\mathrm{a}=$ Total number of collected soil samples in tested plant.

$\mathrm{b}=$ Number of positive samples $/ \mathrm{a} \times 100$

$\mathrm{c}=$ Average number of nematodes $/ 250 \mathrm{~g}$ soil. 
In El-Monufia governorate soil samples, fourteen nematode genera were detected in the soil samples of spinach plants while soil samples of Swiss chard and table beet showed the presence of 11 and 8 nematode genera, respectively. The root-knot nematode was the most frequent nematodes with $56-72 \% \mathrm{FO}$ and PD of $301-515 \quad \mathrm{~J}_{2}{ }^{\prime} \mathrm{s} / 250 \mathrm{~g}$ soil. The genera Tylenchorhynchus, Pratylenchus and Helicotylenchus showed $25-56 \%$ FO and PD of $148-313$ nematodes $1250 \mathrm{~g}$ soil. The cyst nematodes (Heterodera spp.) exhibited $21-61 \%$ FO and PD of $181-498 \mathrm{~J}_{2}$ 's $/ 250 \mathrm{~g}$ soil. On the other hand, the genera Criconema, Criconemella, Ditylenchus, Hoplolaimus, Psilenchus, Rotylenchulus, Trichodorus, Tylenchus and Xiphinema showed $2-27.8 \%$ FO and $60-268$ nematodes $/ 250 \mathrm{~g}$ soil (Table 4).

In Kafr El-Sheikh governorate soil samples, twelve nematode genera were detected in the soil samples of spinach, Swiss chard and table beet plants. The genera Meloidogyne was the most frequent nematodes with 37 - 67\% FO and PD of 252 - $295 \mathrm{~J}_{2}$ 's $/ 250 \mathrm{~g}$ soil. The genera Tylenchorhynchus, Pratylenchus and Helicotylenchus showed $22-48 \%$ FO and PD of $66-$ 236 nematodes $/ 250 \mathrm{~g}$ soil. The cyst nematodes (Heterodera spp.) exhibited $15-40 \%$ FO and PD of $200-229 \mathrm{~J}_{2}$ 's $/ 250 \mathrm{~g}$ soil. On the other hand, the genera Criconema, Criconemella, Hoplolaimus, Psilenchus, Rotylenchus, Tylenchus and Xiphinema showed 4-27 $\%$ FO and $55-205$ nematodes $/ 250$ g soil (Table 5).
Data in Table 6 indicated that the results of the morphological study show that only three species of the root-knot nematodes namely $M$. arenaria, $M$. incognita and $M$. javanica were identified in the collected galled root samples from spinach, Swiss chard, and table beet plants. It is evident that $M$. incognita was very common and widely distributed in north Egypt with frequency of occurrence (FO) of $57-73 \%$, followed by M. javanica with FO of $20-34 \%$, whereas $M$. arenaria had the lowest FO of $7-9 \%$. These results are in agreement with those of other workers (Ibrahim and Mokbel, 2009; Ibrahim and Handoo, 2015; 2016; Ibrahim et al., 2017).

In the present study, soil and root samples collected from the different surveyed districts in five governorates of spinach, table beet, and Swiss chard clarified the presence of 15 genera of plant parasitic nematodes. Some of plant parasitic nematodes cause dangerous quantity and quality losses to various plants in Egypt (Ibrahim and El- Sharkawy, 2001). Root knot nematode (Meloidogyne spp.) acts as one of the most pathogenic nematodes, as it distributes in the most Egyptian soils (Korayem et al., 2014; Ibrahim et al., 2000, 2010). Although some researches in Egypt were carried out to study the relationship between $H$. schachtii and certain crops (Ibrahim et al., 2016, 2017).

Table 4. Frequency of occurrence (FO) and population density (PD) of plant parasitic nematode genera present in soil samples of spanich, Swiss chard and table beet plants in El-Monufia governorate

\begin{tabular}{lcccccc}
\hline \multirow{1}{*}{ Genus } & \multicolumn{2}{c}{$\begin{array}{c}\text { Spinach } \\
(\mathbf{1 5 4})^{\mathbf{a}}\end{array}$} & $\begin{array}{c}\text { Swiss chard } \\
\mathbf{( 3 9 )}\end{array}$ & \multicolumn{2}{c}{$\begin{array}{c}\text { Table beet } \\
(\mathbf{1 8})\end{array}$} \\
\cline { 2 - 7 } & $\mathbf{F O \%}$ & $\mathbf{P D}$ & $\mathbf{F O \%}$ & $\mathbf{P D}$ & $\mathbf{F O \%}$ & PD \\
\hline Criconema & $10.4^{\mathbf{b}}$ & $220^{\mathbf{c}}$ & 10.3 & 75 & 16.7 & 220 \\
Criconemella & 8.4 & 268.4 & 17.9 & 90 & ------ & ------ \\
Ditylenchus & 1.9 & 101.7 & 12.8 & 60 & ----- & ----- \\
Helicotylenchus & 42.2 & 250.7 & 43.6 & 147.6 & 44.4 & 160 \\
Heterodera & 20.8 & 497.7 & 38.5 & 289.1 & 61.1 & 180.9 \\
Hoplolaimus & 5.2 & 256.2 & 15.4 & 105 & 27.8 & 166 \\
Meloidogyne & 55.8 & 515.3 & 64.1 & 300.6 & 72.2 & 306.2 \\
Pratylenchus & 40.9 & 294.6 & 43.6 & 224.7 & 55.6 & 154 \\
Psilenchus & 1.9 & 136.6 & ------ & ------ & ------ & ------ \\
Rotylenchulus & 8.4 & 217.9 & ----- & ----- & ----- & ----- \\
Trichodorus & 4.5 & 224.3 & ------ & ---- & ----- & ----- \\
Tylenchorhynchus & 25.3 & 296.2 & 30.8 & 256.7 & 38.8 & 312.9 \\
Tylenchus & 7.8 & 210.1 & 15.4 & 150 & ------ & ----- \\
Xiphinema & 4.5 & 85.7 & 12.8 & 130 & 16.7 & 140 \\
\hline
\end{tabular}

$\mathrm{a}=$ Total number of collected soil samples in tested plant.

$\mathrm{b}=$ Number of positive samples/ $\mathrm{a} \times 100$

$\mathrm{c}=$ Average number of nematodes $/ 250 \mathrm{~g}$ soil. 
Table 5. Frequency of occurrence (FO) and population density (PD) of plant parasitic nematode genera present in soil samples of spanich, Swiss chard and table beet plants in Kafr El-Sheikh governorate

\begin{tabular}{lcccccc}
\hline \multirow{1}{*}{ Genus } & \multicolumn{2}{c}{$\begin{array}{c}\text { Spinach } \\
(\mathbf{2 7})^{\mathbf{a}}\end{array}$} & \multicolumn{2}{c}{$\begin{array}{c}\text { Swiss chard } \\
(\mathbf{2 7 )}\end{array}$} & \multicolumn{2}{c}{$\begin{array}{c}\text { Table beet } \\
(\mathbf{1 5})\end{array}$} \\
\cline { 2 - 7 } & $\mathbf{F O \%}$ & $\mathbf{P D}$ & $\mathbf{F O \%}$ & $\mathbf{P D}$ & FO\% & PD \\
\hline Criconema & $18.5^{\mathbf{b}}$ & $112^{\mathbf{c}}$ & 14.8 & 90 & 20 & 120 \\
Criconemella & ------ & ------ & ------ & ------ & 13.3 & 75 \\
Helicotylenchus & 22.2 & 65.8 & 25.9 & 82.9 & 30.1 & 88 \\
Heterodera & 33.3 & 218.9 & 14.8 & 200 & 40 & 228.6 \\
Hoplolaimus & 7.4 & 100 & 14.8 & 132.5 & ------ & ----- \\
Meloidogyne & 66.6 & 252 & 37 & 254.8 & 60 & 294.6 \\
Pratylenchus & 48.1 & 235.8 & 33.3 & 165.6 & 46.7 & 211 \\
Psilenchus & 14.8 & 205 & 11.1 & 166.6 & ------ & ----- \\
Rotylenchus & ----- & ----- & 14.8 & 120 & 26.7 & 152.5 \\
Tylenchorhynchus & 40.7 & 117.2 & 40.7 & 124 & 33.3 & 214 \\
Tylenchus & 7.4 & 90 & 11.1 & 105 & 13.3 & 80 \\
Xiphinema & 3.7 & 55 & ------- & ------ & 13.3 & 65 \\
\hline
\end{tabular}

$\mathrm{a}=$ Total number of collected soil samples in tested plant.

$\mathrm{b}=$ Number of positive samples $/ \mathrm{a} \times 100$

$\mathrm{c}=$ Average number of nematodes $/ 250 \mathrm{~g}$ soil.

Table 6. Frequency of occurrence of the root-knot nematodes Meloidogyne arenaria, M. incognita and M. javanica associated with host plants in Alexandria, El-Behera, El-Gharbia, El-Monufia and Kafr El-Sheikh governorates

\begin{tabular}{lcccc}
\hline \multirow{2}{*}{ Host plant } & $\begin{array}{c}\text { No. of collected soil samples } \\
\text { infested with Meloidogyne }\end{array}$ & \multicolumn{3}{c}{ Frequency of occurrence \% $^{\mathbf{a}}$} \\
\cline { 3 - 5 } & spp. & M. arenaria & M. incognita & M. javanica \\
\hline Spinach & 289 & 7.3 & 72.7 & 20.0 \\
Swiss chard & 101 & 8.9 & 60.4 & 30.7 \\
Table beet & 97 & 9.3 & 56.7 & 34.0 \\
\hline
\end{tabular}

$\mathrm{a}=$ Number of positive samples/ Number of collected soil samples infested with Meloidogyne spp. $\mathrm{x} 100$.

Nematode species associated with spinach include cyst (Heterodera schachtii), lesion nematode (Pratylenchus penetrans) and root-knot nematodes (Meloidogyne arenaria, M. hapla, M. incognita, M. javanica) (Olthof and Potter, 1973; Olthof et al., 1974; Potter and Olthof, 1974; Manachini et al., 2003). Recently, severe infection of spinach by $M$. incognita was found in commercial fields of Andalusia, southern Spain (Castillo and Jiménez-Díaz, 2003). Meloidogyne spp. are the most common and damaging nematodes of spinach in several countries (Potter and Olthof, 1993). Previous investigations reported that $M$. incognita is potential pathogens for spinach and table beet (Anamika, 2015; Dammini Premachandra and Gowen, 2015). Lance nematode Hoplolaimus indicus has also been reported associated with table beet in India (Singh and Kumar, 2013). Moreover, Spinach, table beet, and Swiss chard were efficient hosts for $H$. schachtii and $H$. trifolii in the Netherlands (Steele et al., 1983).

In brief, the collected soil samples from certain districts in the five surveyed governorates clarified the distribution of plant parasitic nematodes under the predominant environmental conditions and soil types in the surveyed fields. More research is needed to further identify other genera and species of phytoparasitic nematodes that might occur in Egypt. This helps in developing appropriate necessary plans for managing these nematode pests by eco-friendly methods leading to an increase in an economic production and safe agricultural byproducts.

\section{REFERENCES}

Adam, M., H. Heuer, E. M. Ramadan, M. A. Hussein and J. Hallmann. 2013. Occurrence of plant-parasitic nematodes in organic farming in Egypt. International $J$. of Nematology. 23: $82-90$.

Anamika. 2015. Study on Pathogenicity Test of Meloidogyne incognita on Different Vegetable Crops. J. of Agricultural S. 7(3): $105-110$.

Ayoub, S. M. 1980. Plant nematology, an agriculture training Aid. Nema. Aid. Puplications, Sacramento, California, U.S.A, 195pp. 
Castillo, P. and R. M. Jiménez-Díaz. 2003. First report of Meloidogyne incognita infecting spinach in Southern Spain. Phytopathology. 87:p 874 (abstract).

Dammini Premachandra, W. T. S. and S. R. Gowen. 2015. Influence of pre-plant densities of Meloidogyne incognita on growth and root infestation of spinach (Spinacia oleracea L.) (Amaranthaceae) - an important dimension towards enhancing crop production. J. on Food, Agriculture and Society. 3 (2): $18-26$.

Golden, A. M. 1986. Morphology and identification of cyst nematodes. In: Lamberti, F. and Taylor, F. E. (Eds). Cyst Nematodes, New York: Plenum Press. 23 - 45pp.

Handoo, Z. 2000. A key and diagnostic compendium of the species of the genus Tylenchorhynchus cobb, 1913 (nematode: Belonolaimidae). J. of Nematology, 32: 20 34.

Ibrahim, I. K. A. and T. A. El-Sharkawy. 2001. Genera and species of phytoparasitic nematodes and the associated host plants in Egypt. Advanced Agriculture Research. 3: $75-95$.

Ibrahim, I. K. A. and A. A. Mokbel, 2009. Occurrence and distribution of the root-knot nematodes Meloidogyne spp. and their host plants in northern Egypt. Egypt. The Egyptian J. of Experimental Biology (Botany). 5: 125 129.

Ibrahim, I. K. A., Z. A. Handoo. 2015. Survey of phytoparasitic nematodes associated with some crop plants in northern Egypt. J. of Nematology. 47(3): 247 - 250.

Ibrahim, I. K. A. and Z. A. Handoo. 2016. Occurrence of phytoparasitic nematodes on some crop plants in northern Egypt. Pakistan J. of Nematology. 34(2): 163 - 169.

Ibrahim, I. K. A., Z. A. Handoo and A. A. El-Sherbiny. 2000. A survey of phytoparasitic nematodes on cultivated and non-cultivated plants in north western Egyptian. J. of Nematology. 32: $478-485$.

Ibrahim, I. K. A., A. A. Mokbel and Z. A. Handoo. 2010. Current status of phytoparasitic nematodes and their host plants in Egypt. Nematropica. 40: 239 - 262.

Ibrahim, I. K. A., Z. A. Handoo and A. B. A. Basyony. 2017. The cyst nematodes Heterodera and Globodera species in Egypt. Pakistan J. of Nematology. 35(2): 151 - 154.

Korayem, A. M., M. M. A. Youssef, M. M. M. Mohamed and A. M. S. Lashein. 2014. A Survey of plant parasitic nematodes associated with different plants in North Sinai. Middle East J. of Agriculture Research. 3: 522 - 529.

Mai, W. F. and H. H. Lyon. 1975. Pictorial key to general of plant-parasitic nematodes. $4^{\text {th }}$ edition, Cornell University Press, Ithaca. $172 \mathrm{pp}$.
Manachini, B., S. Landi, and M. Agosti. 2003. Attacchi di Meloidogyne hapla Chitwood su Lactuca sativa L. e Spinacia oleracea L. nell'Italia Settentrionale. Informatore Fitopatologico. 4: $53-64$.

Müller, R., P. S. Gooch, M. R. Siddiqi and D. J. Hunt. 1985. C.I.H. descriptions of plant-parasitic nematodes. Commonwealth Institute of Parasitology, 395A Hatfield Road, St. Albans, Herts., Al 40XQ, U.K.

Mulvey, R. H. and A. M. Golden. 1983. An illustrated key to the cyst forming genera and species of Hoteroderidae in the Western Hemisphere with specirs morphometetrics and distribution. J. of Nematology, 15: 1 - 59.

Olthof, T. H. A. and J. W. Potter. 1973. The relationship between population densities of Pratylenchus penetrans and croplosses in summer-maturing vegetables in Ontario. Phytopathology. 63: 577 - 582.

Olthof, T. H. A., J. W. Potter and E. A. Peterson. 1974. Relationship between population densities of Heterodera schachtii and losses in vegetable crops in Ontario. Phytopathology. 64: 549 - 554.

Potter, J. W., and T. H. A. Olthof. 1974. Yield losses in fallmaturing vegetables relative to population densities of Pratylenchus penetrans and Meloidogyne hapla. Phytopathology. 64: 1072-1075.

Potter, J. W. and T. H. A. Olthof. 1993. Nematode pest of vegetable crops. In: Evans, K., Trudgill, D. L., Webster, J. M., eds. Plant Parasitic Nematodes in Temperate Agriculture. Wallingford, UK: CAB International. 171207.

Preyer, A. 1901. On a new banana disease in Egypt. J. of Khedivial Agriculture Society. 3: 242.

Singh, R. and U. Kumar. 2013. Assessment of Nematode Distribution and Yield Losses in Vegetable Crops of Western Uttar Pradesh in India. International J. of Sci. and Research. 4(5): $2812-2816$.

Steele, A. E., H. Toxopeus, and W. Heijbroek. 1983. Susceptibility of plant selections to Heterodera schachtii and a race of $H$. trifolii parasitic on sugar beet in The Netherlands. J. of Nematology. 15(2): 281 - 288.

Subbotin, S. A., M. Mundo-Ocampo, and J. G. Baldwin. 2010. Systenatics of cyst nematodes (Nematoda: Heteroderinae). Nematolgy Monographs and Perspectives 8, Parts A and B, Leiden, The Netherlands. Brill. 512 pp.

Taylor, A. L. and J. A. Sasser. 1978. Biology, identification and control of root-knot nematodes (Meloidogyne species). Coop Publ. Dep. Plant pathology. North Carolina, state Univ. and U.S. Agency Int. Dev. Raleigh, NC. $111 \mathrm{pp}$. 


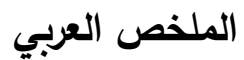

\section{حصر النيماتودا المتطفلة المصاحبة لنباتات السبانخ والسلق وبنجر المائدة في شمال جمهورية مصر العربية}

أيمن بسيونى عبده بسيونى، ابراهيم خيري عتريس ابراهيم، صابرين محمد على زيادة، مها عادل ابراهيم كونه

'(Heterodera) (Helicotylenchus)

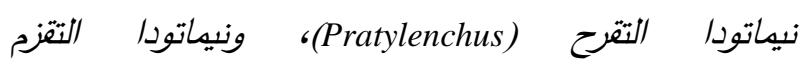
(Tylenchorhynchus) Criconema, Criconemella, Tylenchus Ditylenchus, الأجناس الأخرى التى تم التعرف عليها وهى Hoplolaimus, Psilenchus, Rotylenchulus, Rotylenchus, Trichodorus, Xiphinema أنواع نيماتودا تعقد الجذور Meloidogyne arenaria, M. incognita, M. javanica Heterodera schactii, H. trifolii وبنجر المائدة ويعتبر ذلك أول تسجيل لهذه النيماتودا على هذه النباتات فى مصر • وقد أظهرت نتائج الحصر أن نباتات السبانخ والسلق وبنجر المائدة قد تعتبرعوائل نباتية جديدة لمعظم أجناس النيماتودا التى تم التعرف عليها فى هذه

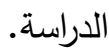

أجريت دراسة لحصر النيماتودا المتطفلة المصاحبة لنباتات السبانخ والسلق وبنجر المائدة فى خمسة محافظات فى شمال جمهورية مصر العربية خلال المواسم الزراعية

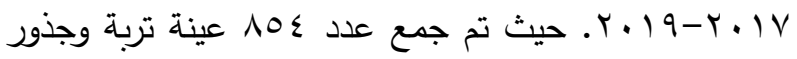
من محاصيل الخضر التى تمت دراستها. وكانت المحافظات التى تم مسحها وعدد عينات التربة الخاصة بكل منها

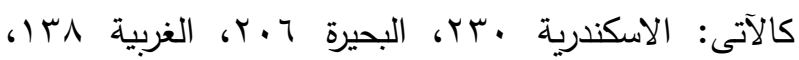
المنوفية I|Y، كفر الثيخ 99 عينة تربة وجذور • وقد تم استخلاص النيماتودا الموجودة فى عينات التربة وتعريفها وتسجيل عددها تحت الميكرسكوب الضوئى المركب. وقد احتوت عينات التربة والجذور التى تم جدعها على عدد 10

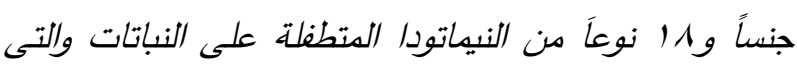
تم تسجيلها لأول مرة على نباتات السبانخ والسلق وبنجر المائدة فى جههورية مصر العربية. وقد كانت نيماتودا تعقد الجذور (Meloidogyne) هى الأكثر شيوعاً فى عينات التربة والجذور المختبرة، تليها كل من النيياتودا الحلزونية 